\title{
Evaluation of relative sampling methods for population estimation of the pepper weevil, Anthonomus eugenii Cano (Coleoptera: Curculionidae)'
}

\author{
Alejandro E. Segarra-Carmona and Alberto Pantoja ${ }^{2}$
}

\begin{abstract}
Five sampling methods were evaluated simultaneously for their efficiency in estimating pepper weevil (Anthonomus eugenii Cano) populations. The use of yellow sticky traps was assessed superior to other methods when correlated with direct weevil counts. Comparison between sticky traps of eight different colors indicated that yellow and white traps are significantly more attractive to pepper weevils than light green, red, dark green, gray, blue or black. Commercially available Pherocon AM traps were tested for efficiency. Weevil catch in these traps was positively correlated with population density, but relationship was weak and weekly calch erratic. Factors affecting trap efficiency are mentioned.
\end{abstract}

\section{RESUMEN}

Comparación de métodos de muestreo para estimar la población del gorgojo del pimiento

\begin{abstract}
Una evaluación de cinco métodos de muestreo indicó la superioridad de trampas pegajosas amarillas en la estimación de los niveles de densidad del picudo del pimiento, Anthonomus eugenii Cano. Una comparación entre trampas pegajosas en ocho colores resultó en la determinación de que los colores amarillo y blanco atraen significativamente más adultos que ołros colores. Además, se evaluó la utilidad y eficacia de las trampas comerciales Pherocon AM. Se enconiró que la captura en éstas podía correlacionarse con los niveles de densidad del picudo del pimiento observados en el campo. Sin embargo, esła correlación resultó débil y errática debido en la mayoría de los casos a deficiencias en su diseño, con respecto a esie picudo y su hábitat.
\end{abstract}

\section{INTRODUCTION}

The pepper weevil, Anthonomus eugenii Cano, was introduced to Puerto Rico around 1980. Since then, this weevil has become an important limiting factor for the production of peppers, especially in the northwestern districts of the island (1). At present, little information is available on management strategies for this pest throughout its geographical

${ }^{1}$ Manuscript submitted to Editorial Board 2 February 1988.

${ }^{2}$ Assistant Entomologists, Department of Crop Protection, Agricultural Experiment Station, College of Agricultural Sciences, University of Puerto Rico. 
range. Recent studies on integrated pest management (IPM) strategies for the pepper weevil have found that because of their cost (12), traditional direct sampling methods hinder applicability of responsive programs (i.e., economic thresholds). Only through more economical sampling schemes could responsive-based IPM programs be applicable to this pest on peppers in Puerto Rico (12).

Many sampling methods have been devised to estimate population levels of insect pests. Comparisons between different sampling methods is common practice in the search of efficient pest population estimation (3). In the past, absolute methods such as direct adult counting have been used to determine pepper weevil population densities (6). Only the relative 'drop cloth' sampling method has been used in past pepper weevil studies (10) in Puerto Rico. Other population sampling techniques for testing are promising, such as colored sticky traps $(7,9,11,14)$, sweep netting $(2,5)$, and detergent water traps $(4,13)$.

The objective of this work was to evaluate and compare simultaneously various sampling methods with special emphasis on their adaptability into responsive IPM programs.

\section{MATERIALS AND METHODS}

Sampling methods were evaluated in established 'Cubanelle' pepper fields for 8 consecutive weeks at the Isabela Substation from October to December 1985. Fields had not been sprayed with insecticide for 60 days before beginning sampling tests. Planting density was 23,920 plants/ha. Sampling was conducted weekly from 0900 to 1030 . Each weekly sampling consisted of different routines depending on the sampling method, as follows: 1) sweep netting: consisted of five bouts of 20 sweeps each with a 46-cm (diameter) sweep net; 2 ) drop-cloth: 20 randomly selected plants were beaten on a $0.83 \mathrm{~m}^{2}$ drop cloth; 3) detergent-water pans: number of weevils falling into four $30.5 \times 20.3 \times 15.7 \mathrm{~cm}$ yellow-painted pans half-filled with detergent solution. Pans were raised $10 \mathrm{~cm}$ from the ground and serviced weekly; 4) sticky colored traps: boards $167.6 \times 10.2$ cm were painted yellow, white, light green, dark green, blue, red, gray or black. Boards were thoroughly covered with "Stikem"a insect adhesive (Seabright Enterprises, Emeryville, Ca.). One replicate of each colored board was placed in each of two blocks following a randomized complete block design. Spectral analysis was conducted for colors with the use of a Beckmann Spectrophotometer equipped with an integrating sphere attachment. Only visible spectra (300 to $700 \mathrm{~nm}$ ) were analyzed; 5) direct counting: twenty randomly selected plants were sequentially selected

${ }^{3}$ Trade names in this publication are used only to provide specific information. Mention of a trade names does not constitute a warranty of equipment or materials by the Agricultural Experiment Station of the University of Puerto Rico, nor is this mention a statement of preference over other equipment or materials. 
(i.e., first plant was chosen randomly, and from then on every fifth plant was sampled until 20 plants were sampled) and all adult weevils counted. Sampling method comparisons were made by correlation analysis.

Additionally, Pherocon AM traps by Zoecon were placed inside a second pepper planting from March to June 1986. Each trap was placed in the center of a 'Cubanelle' pepper plot containing 100 plants. Planting conditions were identical to those described by Segarra and Pantoja (12). Correlation analysis was used to determine their population predictive efficiency.

\section{RESULTS AND DISCUSSION}

Pepper weevil responsive management depends to a great extent on careful population monitoring and scouting. These activities are responsible for large proportions of total control expenditures, if direct counting is used as scouting method (12). Therefore, any sampling method that could reduce scouting costs while accurately predicting weevil population levels, is very desirable. Of the 4 sampling methods tested, only yellow sticky traps adult counts significantly correlated with direct plant counts (table 1). Other methods were ineffective in eapturing adult weevils (i.e., detergent-water pans) or caused severe damage to pepper plants (i.e., drop-cloth and sweep netting).

Yellow sticky boards were the most attractive to pepper weevil adults (fig. 1). The order of attractancy was yellow $>$ white $\geq$ light green $>$ red $>$ dark green $\geq$ gray $\geq$ blue $\geq$ black. Spectral analyses of these colors indicate that preferred colors show reflectance peaks between 540 and $600 \mathrm{~nm}$ (fig.2). Non-attractive colors to weevils such as dark green, gray, blue, and black showed no peaks in that area of the visible spectrum. Red sticky traps were intermediate in attractancy to adult weevils. Color clues provided to pepper weevils by red traps are unknown, but attractancy could be related to the spectral changes most Capsicum spp. fruits undergo during their maturation process (i.e., green to yellow to red).

Pherocon AM traps, which have been successfully used in trapping other insects, appeared only marginally effective in predicting weevil

TABLE 1.-Correlation coefficient matrix between five sampling methods of the pepper weevil. $D I R=$ direct count, $Y S T=$ yellow stichy trap, $D C=$ Drop cloth, $S W N=$ sweep net, and $D W T=$ detergent water trap

\begin{tabular}{llllll}
\hline & \multicolumn{1}{c}{ DIR } & \multicolumn{1}{c}{ YST } & DC & SWN & DWT \\
\hline DIR & 1.000 & & & & \\
YST & $0.715^{* 1}$ & 1.000 & & & \\
DC & 0.665 & $0.835^{* * *}$ & 1.000 & & \\
SWN & 0.626 & $0.988^{* * *}$ & $0.698^{*}$ & 1.000 & \\
DWT & 0.235 & 0.158 & -0.046 & 0.127 & 1.000 \\
\hline
\end{tabular}

$1 *=\mathrm{P}<0.05$ and $* *=\mathrm{P}<0.01$, respectively. 


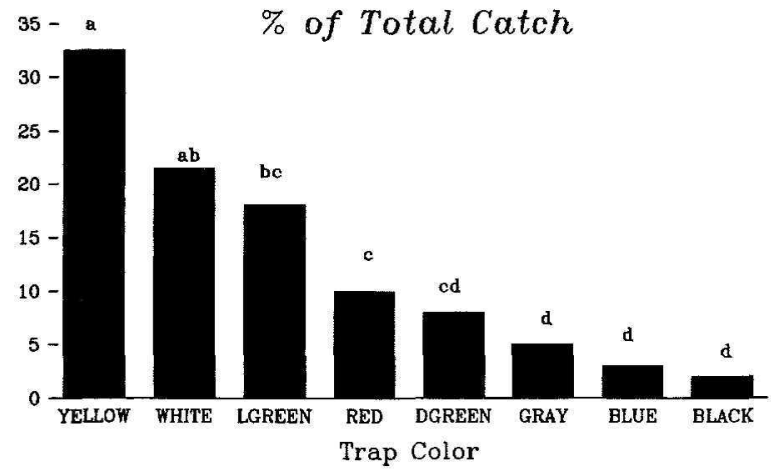

FIG. 1.-Percent of total pepper weevil adults caught weekly in sticky traps of eight different colors.

populations. The number of weevils per plant positively correlated with total trap catch (fig. 3); however, only $31 \%$ of variance could be explained by the obtained model. Similar erratic results have been observed elsewhere (8). Lack of model efficiency could be due to several factors associated with trap quality and design. For example, traps were noticeably prone to color degradation by the action of sunlight, moisture and fungus. All these conditions were prevalent under our 21-day trap substitution regime. In addition, the small size of the trap and its poor coverage of weevil flight planes may have influenced its fair rating.

\section{CONCLUSION}

The key element of responsive IPM systems lies in significant cost reductions when compared with prophylactically oriented programs. Today, scouting costs represent a substantial expenditure of responsive programs. Fortunately, scouting costs can be significantly reduced if effective and easy-to-use pest monitoring tools are developed for and used by the farmer. Yellow sticky traps appear to be such an inexpensive weevil population monitoring system for farmer's use. At an estimated cost of $\$ 1.25$ per trap and a trap density of $10 \mathrm{traps} / \mathrm{ha}$ the farmer could reduce scouting costs more than $80 \%$ throughout one season as compared with costs of direct weevil count methods. Such sizable reduction in control costs should make responsive IPM the main component of pepper weevil management in Puerto Rico. 

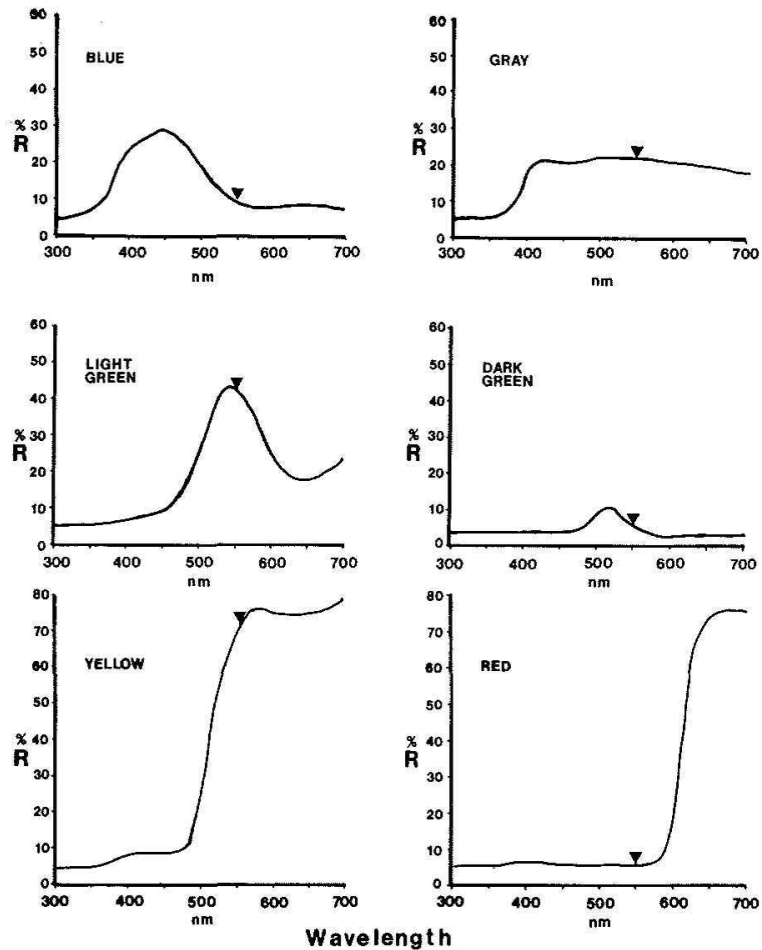

FIG. 2.-Reflectance (\%R) spectra of colors used on sticky traps tested. Inverted triangle marks $550 \mathrm{~nm}$. 


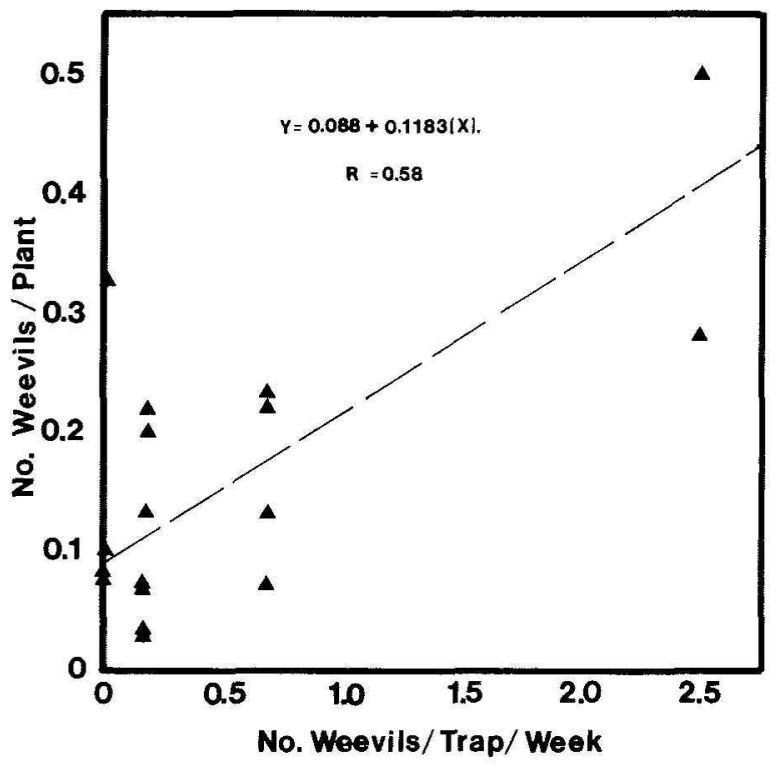

FiG. 3.-Relationship between number of weevils per plant and weekly trap catch. Broken line represents predictive linear equation.

\section{LITERATURE CITED}

1. Abreu, E. and C. Cruz, 1985. The oecurrence of the pepper weevil, Anthonomus eugenii Cano (Coleoptera: Cureulionidae). J. Agric. Univ. P. R. 69: 223-24.

2. Cherry, R. H., K. A. Wood and W. G. Ruesnik, 1977. Emergence trap and sweep sampling for adults of the potato leafhopper from alfalfa. J. Econ. Entomol. 70: $179-82$.

3. Edelson, J. V., 1986. Comparison of sempling methods for insect pests of cantaloupe. J. Econ. Entomol. 79: 266-70.

4. Finch, S. and G. Skinner, 1974. Some factors affecting the efficiency of water traps for capturing cabbage root flies. Ann. Appl. Biol. 77: 213-26.

5. Fleischer, S. J. and W. A. Allen, 1982. Field counting efficieney of sweep-net samples of adult potato leafhoppers (Homoptera: Cicadellidae) in Alfalfa. J. Econ. Entomol. 75: $837-40$.

6. Gordon Mendoza, R., 1984. Control químico y biología del picudo del pimiento $A n$ thonomus eugenii Cano (Coleoptera: Curculionidae) en Puerto Rico. M.Sc. Thesis. Univ. P. R., Mayagiez Campus. 
7. Hein, G. L. and J. J. Tollefson, 1985. Use of Pherocon AM traps as seouting tool for predicting damage by corn rootworm (Coleoptera: Chrysomelidae) larvae. J. Econ. Entomol. 78: 200-03.

8. Karr, L. L. and J. J. Tollefson, 1987. Durability of Pheroeon AM traps for adult western and northern corn rootworm (Coleoptera: Chrysomellidae) sampling. $J$. Econ. Entomol. 80: 891-96.

9. Klostermeyer, L. E. 1985. Japanese beetle traps: 1984 comparison. Tenn. Farm and Home. July Issue pp. 19-22.

10. Ozaki, H. Y. and W. E. Genung, 1982. Inseeticide evaluation for pepper weevil control. Proc. Fla. State Hort. Soc. 95: 347-48.

11. Prokopy, R. J., 1968. Visual responses of the apple maggot flies, Rhagoletis pomonella (Diptera: Tephritidae): Orchard studies. Entomol. Exp. Appl. 11: 403-22.

12. Segarra-Carmona, A. E. and A. Pantoja, 1988. Sequential sampling plan, yield-loss component analysis and economic thresholds for Anthonomus eugenii Cano (Coleoptera; Curculionidae). J. Agric. Univ. P. R. 72(3): 375-85.

13. Southwood, T. R. E., 1978. Ecological methods. 2nd ed, Chapman and Hall. New York.

14. Weseloh, R. M., 1986. Host and microhabitat preferences of forest parasitic hymenoptera: Inferenees from captures on colored sticky panels. Environ. Entomol. 15: $64-70$. 
